\title{
Genome-wide survey of cytochrome P450 genes in the salmon louse Lepeophtheirus salmonis (Krøyer, 1837)
}

Joseph L. Humble1', Greta Carmona-Antoñanzas' ${ }^{1}$, Carol M. McNair ${ }^{1}$, David R. Nelson², David I. Bassett' Ingibjørg Egholm, James E. Bron ${ }^{1}$, Michaël Bekaert ${ }^{1}$ and Armin Sturm ${ }^{* *}$

\begin{abstract}
Background: The salmon louse (Lepeophtheirus salmonis) infests farmed and wild salmonid fishes, causing considerable economic damage to the salmon farming industry. Infestations of farmed salmon are controlled using a combination of non-medicinal approaches and veterinary drug treatments. While L. salmonis has developed resistance to most available salmon delousing agents, relatively little is known about the molecular mechanisms involved. Members of the cytochrome P450 (CYP) superfamily are typically monooxygenases, some of which are involved in the biosynthesis and metabolism of endogenous compounds, while others have central roles in the detoxification of xenobiotics. In terrestrial arthropods, insecticide resistance can be based on the enhanced expression of CYPs. The reported research aimed to characterise the CYP superfamily in L. salmonis and assess its potential roles in drug resistance.
\end{abstract}

Methods: Lepeophtheirus salmonis CYPs were identified by homology searches of the genome and transcriptome of the parasite. CYP transcript abundance in drug susceptible and multi-resistant L. salmonis was assessed by quantitative reverse transcription PCR, taking into account both constitutive expression and expression in parasites exposed to sublethal levels of salmon delousing agents, ecdysteroids and environmental chemicals.

Results: The above strategy led to the identification of 25 CYP genes/pseudogenes in L. salmonis, making its CYP superfamily the most compact characterised for any arthropod to date. Lepeophtheirus salmonis possesses homologues of a number of arthropod CYP genes with roles in ecdysteroid metabolism, such as the fruit fly genes disembodied, shadow, shade, spook and Cyp 18a1. CYP transcript expression did not differ between one drug susceptible and one multi-resistant strain of L. salmonis. Exposure of L. salmonis to emamectin benzoate or deltamethrin caused the transcriptional upregulation of certain CYPs. In contrast, neither ecdysteroid nor benzo[a]pyrene exposure affected CYP transcription significantly.

Conclusions: The parasite L. salmonis is demonstrated to possess the most compact CYP superfamily characterised for any arthropod to date. The complement of CYP genes in L. salmonis includes conserved CYP genes involved in ecdysteroid biosynthesis and metabolism, as well as drug-inducible CYP genes. The present study does not provide evidence for a role of CYP genes in the decreased susceptibility of the multiresistant parasite strain studied.

Keywords: Drug resistance, Aquaculture, Salmon farming, Lepeophtheirus salmonis, Caligidae, Cytochrome P450

\section{Background}

Caligid sea lice (Copepoda, Crustacea) are ectoparasites of marine fish, feeding on the mucus, skin and blood of

*Correspondence: armin.sturm@stir.ac.uk

1 Institute of Aquaculture, University of Stirling, Stirling FK9 4LA, Scotland, UK Full list of author information is available at the end of the article their hosts [1]. The salmon louse, Lepeophtheirus salmonis (Krøyer, 1837) infests wild and farmed salmonid fishes and is divided into two allopatric subspecies, which inhabit the North Atlantic and the North-East Pacific [2]. Caligid infestations are a major obstacle to salmon farming due to their detrimental effects on the health and welfare of cage-cultured fish [3], to the economic costs 
associated with decreased yield and to the costs of parasite control measures $[1,4]$. For 2017, global costs associated with sea louse infections and their control have been estimated at $\sim € 700$ million [5]. In addition, concerns have been raised regarding the potential for detrimental impacts of transmission of farm-origin salmon lice to wild salmonid populations, which can be particularly vulnerable to salmon lice associated mortality at the migratory smolt phase of the anadromous life-cycle [6].

At salmon production sites, L. salmonis are managed using an integrated pest management strategy (IPM) employing a range of control approaches to maximize results. In the last five years, there has been an increased implementation of non-medicinal control strategies, which include co-culture with cleaner fish $[7,8]$, cage designs that reduce infection pressure [9], immunostimulants [10], treatments with freshwater and thermal delousing [11]. Despite this, L. salmonis control still relies significantly on a limited range of veterinary drugs [4]. Licensed salmon delousing agents currently available in the UK include the organophosphate azamethiphos, the pyrethroid deltamethrin (DM) and the non-specific oxidant hydrogen peroxide, all of which are applied as bath treatments, and the macrocyclic lactone emamectin benzoate (EMB), which is administered as an in-feed medication [12]. The repeated use of the same or similarly acting compounds can favour the evolution of resistance in parasite populations [13]. Loss of treatment efficacy has been reported for most available drugs [14-17], likely indicative of the development of drug resistance [18-21].

Resistance of terrestrial arthropod pests to insecticides and acaricides is relatively well understood and most commonly involves one or both of two main molecular mechanisms [22]. Resistance can be based on mutations causing specific amino acid substitutions in proteins targeted by the pesticide [23, 24]. Alternatively, resistance can result from enhanced detoxification due to overexpression of enzymes responsible for pesticide metabolism, which typically involves members of three large gene families, the cytochrome P450s (CYPs), carboxylesterases and glutathione transferases [25]. While resistance mechanisms in $L$. salmonis are still incompletely understood, recent studies provide first insights into the molecular determinants involved. Lepeophtheirus salmonis resistance to the organophosphate azamethiphos is a consequence of a point mutation in an acetylcholinesterase gene [18], whereas hydrogen peroxide resistance is associated with increased catalase expression [26]. Resistance of L. salmonis to EMB has been linked to selective sweeps; however, the genes under selection remain to be identified [27]. Pyrethroid resistance is mainly maternally inherited and associated with specific mitochondrial haplotypes [19], with possible additional roles of target site mutations in voltage gated sodium channels [20].

CYPs constitute a large gene superfamily of haemcontaining enzymes present in prokaryotes and eukaryotes [28]. Metazoan CYPs are membrane-bound, locating either to the endoplasmic reticulum or to the inner mitochondrial membrane, and catalyse a diverse range of reactions related to the metabolism of endogenous and foreign chemicals [29]. The CYP superfamily shows high complexity, both between and within species, with the number of CYP loci in arthropod genomes ranging from 36 in the human body louse Pediculus humanus humanus to $>200$ in the tick Ixodes scapularis [30, 31]. In insects, CYP superfamily members mediate steps in the biosynthesis of ecdysteroids [32], juvenile hormone [33] and cuticle long-chain hydrocarbons [34]. CYPs may further be involved in pheromone biosynthesis and odorant degradation at chemosensory sensilla [35]. Furthermore, a number of CYPs contribute to the biochemical defence against xenobiotics and are involved in the metabolic detoxification of phytotoxins [36] and pesticides [35].

In terrestrial arthropods, insecticide resistance can result from the constitutive upregulation of CYPs (reviewed in [35, 37, 38]), as first suggested by the overexpression of the Cyp6g1 gene in DDT-resistant laboratory and field populations of Drosophila melanogaster [39]. For certain insect CYPs, roles as resistance factors have been corroborated by the demonstration of catalytic activity in the metabolism of relevant compounds [40, 41], protective effect of transgenic overexpression [42], and reversal of resistance by RNA interference [43, 44]. In L. salmonis, roles for CYPs in the toxicology of salmon delousing agents have been suggested based on changes in transcript expression of certain CYPs associated with resistance or previous exposure to treatments $[45,46]$. However, the CYP superfamily of $L$. salmonis has not previously been annotated or systematically assessed regarding its potential roles in drug resistance.

The aim of the present study was to characterise the CYP superfamily in L. salmonis and to obtain insights into potential roles of CYPs in the resistance of this parasite against chemical control agents. CYPs were initially identified by homology searches of $L$. salmonis genome and transcriptome databases, and subsequently annotated and subjected to phylogenetic analyses. Constitutive transcript expression was compared, for CYPs identified in the L. salmonis transcriptome, between laboratory-cultured strains of multi-resistant and drug-susceptible parasites, and the effects of xenobiotic exposure on CYP transcription were also assessed. 


\section{Methods}

\section{Salmon lice husbandry}

Laboratory-cultured strains of $L$. salmonis investigated in this study have previously been described [19, 47]. Strain IoA-00 is susceptible to all current salmon delousing agents, whereas strain IoA-02 has previously been shown to be resistant against EMB and DM. Azamethiphos susceptibility of the strains was determined in this study (see below). Since isolation, the strains have been cultured under identical conditions using Atlantic salmon (Salmon salar L.) as host, as described in detail previously [17, 47]. All experimental infections were conducted under UK Home Office licence, and were subject to prior ethical review and appropriate veterinary supervision. Prior to harvesting parasites for experimental use, salmon carrying sea lice were euthanized by percussive stunning followed by destruction of the brain, according to UK Home Office Schedule 1 requirements. Collected parasites were immediately placed into aerated filtered seawater equilibrated to $12{ }^{\circ} \mathrm{C}$ and allowed to recover for 2 to $6 \mathrm{~h}$ before being randomly allocated to experimental treatments.

\section{Chemical exposure experiments}

Lepeophtheirus salmonis bioassays with azamethiphos (Salmosan Vet ${ }^{\circledR} 500,50 \%$ w/w azamethiphos) were conducted at $12{ }^{\circ} \mathrm{C}$ and involved exposure of parasites to eight drug concentrations $(0.46,1.00,2.15,4.64,10.0$, $21.5,46.4$ and $100 \mu \mathrm{g} / \mathrm{l}$ ) or seawater (controls). Drug and control treatments were run in duplicate, with each replicate containing each 5 adult males and 5 pre-adult-II or early adult females. Following $60 \mathrm{~min}$ of exposure, parasites were transferred to clean seawater and allowed to recover for $24 \mathrm{~h}$ before being rated as normal or impaired [18], using a set of behavioural criteria described in detail before [47]. Response data were assessed and the median effective concentration $\left(\mathrm{EC}_{50}\right)$ derived by probit analysis using Minitab version 16.1.1.

In order to compare transcript expression between drug-susceptible and drug-resistant parasites and to further elucidate potential effects of different environmental and endogenous compounds on transcript abundance, male and female L. salmonis of the above strains were subjected to water-borne chemical exposures of chemicals at sublethal levels. Compounds studied included the salmon delousing agents EMB and DM, the arthropod hormones ecdysone (Ec) and 20-hydroxyecdysone $(20 \mathrm{HEc})$ and the environmental pollutant benzo[a] pyrene (BAP). All compounds studied were of analytical grade purity and obtained from Sigma-Aldrich (Dorset, UK).

$\mathrm{PEG}_{300}$ (polyethylene glycol, $\mathrm{M}_{\mathrm{n}}=300$ ) was used to solubilise EMB and DM, while ethanol was used to solubilise E, 20HE and BAP. The final level of both solvents in treatments and controls was $0.05 \%(\mathrm{v} / \mathrm{v})$. No effects of $\mathrm{PEG}_{300}$ on transcript expression were detected in a previous microarray study [45]. Exposure solutions (EMB: 25 and $150 \mu \mathrm{g} / \mathrm{l}$; DM: 0.05 and $2 \mu \mathrm{g} / \mathrm{l}$; Ec and 20HEc: 0.02 and $0.2 \mu \mathrm{g} / \mathrm{l}$; BAP: 0.003 and $0.03 \mu \mathrm{g} / \mathrm{l}$ ) were prepared using filtered seawater. Reflecting recommended conditions for immersion bath treatments, $L$. salmonis were exposed to DM for $30 \mathrm{~min}$, followed by the transfer of animals to clean seawater and $24 \mathrm{~h}$ of recovery. Exposure to EMB and all other compounds were for $24 \mathrm{~h}$. After exposure and (if applicable) recovery, the viability of parasites was confirmed by ascertaining the absence of behavioural responses defined for bioassays [47], prior to removal of parasites into RNA stabilisation solution (4.54 $\mathrm{M}$ ammonium sulphate, $25 \mathrm{mM}$ trisodium citrate, 20 mM EDTA, pH 5.4). Samples were stored overnight at $4{ }^{\circ} \mathrm{C}$, before transfer to nuclease-free tubes for storage at $-80^{\circ} \mathrm{C}$ pending RNA extraction.

\section{Identification and annotation of $L$. salmonis CYP genes}

In order to identify L. salmonis CYP sequences, a previously published multi-stage L. salmonis transcriptome (EBI ENA reference ERS237607) [48] was screened for CYP genes by conducting parallel tBLASTn searches (cut-off E-value of $10^{-5}$ ), employing as query sequences the full complement of CYP proteins of different arthropods in which the CYP gene superfamily has been annotated (Tigriopus japonicus [49], Paracyclopina nana [50], Daphnia pulex [51], Drosophila melanogaster [52]). Daphnia pulex sequences were obtained from supplementary materials available in the online version of a previous study [51]; see Additional file 1: Table S1 for accession numbers of sequences). The L. salmonis genome assembly LSalAtl2s (metazoa.ensembl.org) was scanned for CYP sequences using the same strategy, with query sequences further including CYP transcripts identified in the L. salmonis transcriptome. Each CYP locus identified by the above strategies was manually annotated following the criteria of the Cytochrome P450 Nomenclature Committee. The CYP superfamily is subdivided into CYP families containing members of $>40 \%$ amino acid identity, and subfamilies comprised of sequences of at least 55\% amino acid identity [53]. CYP names consist of the superfamily designation 'CYP' followed by a number denoting the family and a letter indicating the subfamily, plus a final number attributed to the isoform. Lepeophtheirus salmonis CYP sequences identified and named as described above were confirmed by RT-PCR and sequencing experiments (see below) and deposited in GenBank (see Additional file 2: Table S2 for accession numbers). 


\section{Phylogenetic analyses}

CYPs from L. salmonis (this study) were subjected to phylogenetic analyses together with CYPs from three crustaceans (D. pulex [51], T. japonicus [49], P. nana [50]) and one insect (honeybee, Apis mellifera [54]) (see Additional file 1: Table S1 for accession numbers). Peptide sequences were aligned using GramAlign v3.0 [55] and analysed using IQ-TREE v1.6.9 [56]. The phylogenetic tree was constructed using a maximum likelihood method implementing the GTR model for heterogeneity among sites and the Dayhoff substitution model [-m Dayhoff + G8+FO] with 1000 bootstrapping iterations [-bb 1000].

\section{RNA extraction}

Individual L. salmonis were homogenised in $500 \mu \mathrm{l}$ TriReagent (Sigma-Aldrich) using a bead-beater homogenizer (BioSpec, Bartlesville, Oklahoma, USA) and total RNA was extracted by following the manufacturer's protocols. RNA was resuspended in MilliQ water $(20 \mu$ for females and $15 \mu \mathrm{l}$ for males). RNA purity and concentration was inspected by spectrophotometry using a NanoDrop ND-1000 (Thermo Fisher Scientific, Paisley, UK) and the values for the $260 \mathrm{~nm} / 280 \mathrm{~nm}$ ratio were recorded as within the range of 2.0-2.3, while RNA integrity was assessed by following electrophoresis on horizontal agarose gels and visualization of ethidium bromide-stained bands under UV light.

\section{CDNA synthesis}

Total RNA samples were reverse transcribed using BioScript Reverse Transcriptase (Bioline, London, UK) following the manufacturer's protocols. RNA (300 ng) was combined with anchored oligodT $(1 \mu \mathrm{M}$, Eurofins Genomics, Ebersberg, Germany) and random hexamers (3 $\mu \mathrm{M}$, Qiagen, Manchester, UK), $1 \mu \mathrm{M}$ of dNTPs and nuclease-free water in a volume of $10 \mu$ l. Following incubation at $70{ }^{\circ} \mathrm{C}$ for $5 \mathrm{~min}$ and cooling on ice for $5 \mathrm{~min}$, each reaction aliquot received $4 \mu \mathrm{l}$ RT buffer, $1 \mu \mathrm{l}$ RiboSafe Inhibitor, $1 \mu \mathrm{l}$ of BioScript reverse transcriptase, $1 \mu \mathrm{l}$ DTT $(20 \mathrm{mM})$ and $3 \mu \mathrm{l}$ nuclease-free water. The reactions were then incubated at $25^{\circ} \mathrm{C}$ for $10 \mathrm{~min}, 42{ }^{\circ} \mathrm{C}$ for $30 \mathrm{~min}$ and $85{ }^{\circ} \mathrm{C}$ for $5 \mathrm{~min}$. In addition to samples, negative controls were included that lacked reverse transcriptase. Products were stored at $-20^{\circ} \mathrm{C}$.

\section{RT-PCR and sequencing}

In order to confirm L. salmonis CYP sequences identified in this study, cDNAs were amplified by reverse transcription polymerase chain reaction (RT-PCR) and sequenced (see Additional file 2: Table S2 for primer sequences). PCR reactions were conducted using the Q $5^{\circledR}$ Hot Start High-Fidelity $2 \times$ Master Mix (New England Biolabs,
Hitchin, UK) following the manufacturer's protocol and employing 35 cycles. PCR products were examined by agarose gel electrophoresis and the remaining PCR product was purified (QIAquick PCR Purification Kit, Qiagen) and submitted to a commercial provider for Sanger sequencing. Sequences obtained for the same PCR products were aligned to obtain contiguous cDNA sequences (Table 1), which were deposed in GenBank (see Additional file 2: Table $\mathrm{S} 2$ for accession numbers).

\section{RT-qPCR}

Quantitative reverse transcription polymerase chain reaction (RT-qPCR) was used to determine the transcript abundance of CYP sequences identified in the transcriptome. Six male and six female parasites were analysed for each combination of treatment and strain. Primers were designed using primer-BLAST (NCBI) to anneal to, or surround, intron-exon boundaries when available. Primers for target and reference genes (ribosomal subunit 40S, 40S; elongation factor 1-alpha, ef1a; and hypoxanthine-guanine phosphoribosyltransferase, hgprt) [45] (Additional file 3: Table S3) were used at $300 \mu \mathrm{M}$ with $2.5 \mu \mathrm{l}$ of a 1:20 dilution of the cDNA synthesis reaction with Luminaris Color HiGreen qPCR Master Mix (Thermo Fisher Scientific) in a total volume of $10 \mu \mathrm{l}$. Reactions were performed in technical duplicate for experimental samples and technical triplicate for standard curve, non-template controls and reverse transcriptase controls in a LightCycler 480 II (Roche Diagnostics, Basel, Switzerland) using white 384-well plates. The thermocycling program $\left(95^{\circ} \mathrm{C}\right.$ for $10 \mathrm{~min}$, then 40 cycles of $95{ }^{\circ} \mathrm{C}$ for $15 \mathrm{~s}, 60{ }^{\circ} \mathrm{C}$ for $30 \mathrm{~s}, 72{ }^{\circ} \mathrm{C}$ for $30 \mathrm{~s}$, then $72{ }^{\circ} \mathrm{C}$ for $3 \mathrm{~min}$ ) was followed by melting curve analysis. Relative transcript quantification was achieved by including on each PCR plate a set of serial dilutions of a pool of all experimental cDNA samples, allowing derivation of the estimated relative copy number of the transcript of interest for each sample, this being corrected for the efficiency of the reaction (Additional file 4: Table S4). The normalized expression values were generated by the $\Delta \Delta \mathrm{Ct}$ method [57] and the results expressed as mean normalized ratios between the relative units of each target gene and a reference gene index calculated from the geometric mean of the threshold cycles of the three reference genes.

\section{Statistical analyses}

As a number of RT-qPCR data sets failed tests of homoscedasticity (Minitab version 17), non-parametric tests were used for statistical analysis of the data. All further tests were conducted in $\mathrm{R}$ version 3.4.1, using the packages rcompanion and PMCMR. The Scheirer-Ray-Hare test was used to assess effects of parasite strain and sex/ 
stage on transcript expression. The Kruskal-Wallis test was employed to check for effects of chemical treatments. To control the experiment-wise type I error, sequential Bonferroni correction was applied to account for the simultaneous testing of 21 transcripts [58]. Following significant Kruskal-Wallis results, Dunn's test was used for post-hoc comparisons between chemical treatments to the control group.

\section{Results}

\section{Identification of $L$. salmonis CYPs}

In order to identify CYPs in L. salmonis, homology searches were carried out in a previously published multi-stage transcriptome [48] and a genome assembly (LSalAtl2, metazoan.ensembl.org) of the parasite. In the transcriptome, 25 sequences were identified, all of which except for transcript HACA01014825 could be mapped to gene models of the genome assembly, with some gene models being represented by more than one transcript (Table 1). Transcript HACA01014825 showed signs of pseudogenisation such as multiple in-frame stop codons, mapped to a genome region in supercontig LSalAtl2s111 lacking a gene model. Homology searches of the genome assembly for CYP sequences yielded four further potential CYP loci, three of which were short partial sequences. Taken together, 25 putative CYP genes/pseudogenes were obtained in L. salmonis and named according to the current CYP nomenclature (Table 1). Alignment and assessment of the sequences revealed the conservation of motifs present in arthropod CYPs, namely the helix $\mathrm{C}$, helix I, helix K, PERF and haem binding motifs (Additional file 5: Table S5).

\section{Phylogenetic analyses}

Lepeophtheirus salmonis CYPs were subjected to phylogenetic analysis together with sequences from crustaceans in which the CYP superfamily has been characterised, i.e. the branchiopod Daphnia pulex [51] and the non-parasitic copepods Tigriopus japonicus and Paracyclopina nana [49, 50] (Fig. 1a). Salmon louse CYPs were further analysed regarding their evolutionary relation to CYPs of the honeybee (Apis mellifera) [54] (Fig. 1b). Both analyses differentiated CYP clans as distinct clades, with $L$. salmonis sequences found within the mitochondrial CYP, CYP2 and CYP3 clans. The phylogenetic analysis further suggested that $L$. salmonis possesses homologues of a number of insect Halloween genes encoding CYPs involved in ecdysteroid biosynthesis, including spook/CYP307A1, disembodied/ CYP302A1, shadow/CYP315A1 and shade/CYP314A1 but not phantom/CYP306A1 (Fig. 1b). Furthermore, $L$. salmonis appeared to possess a homologue of CYP18A1, a 26-hydroxylase functioning in ecdysteroid inactivation.

\section{Transcript expression of $L$. salmonis CYPs}

The transcript expression of L. salmonis CYPs was studied using quantitative real-time PCR (RT-qPCR) in two previously characterised laboratory-maintained strains of the parasite. Strain IoA-00 is susceptible to all licensed chemical salmon delousing agents, whereas strain IoA-02 is resistant against EMB, DM and azamethiphos (Additional file 4: Table S4). CYP transcript expression was studied in synchronised parasite cohorts of developmental stages typically used for immobility bioassays (male adult, female preadult-II). Eleven of 21 studied CYP transcripts, including representatives from all clans, were differentially expressed between male adult and female preadult-II lice (Fig. 2). In contrast, differences in CYP transcription between the two strains investigated were not significant (Fig. 2).

The effects of drugs on CYP transcription were studied for two salmon delousing agents, the pyrethroid DM (Fig. 3) and the macrocyclic lactone EMB (Fig. 4). Experiments involved the exposure of IoA-00 and IoA-02 lice to low sublethal concentrations of the compounds $(0.05 \mu \mathrm{g} / \mathrm{l}$ DM; $25 \mu \mathrm{g} / \mathrm{l} \mathrm{EMB}$ ) and both strains were exposed to higher concentrations $(2.0 \mu \mathrm{g} / \mathrm{l} \mathrm{DM}, 150 \mu \mathrm{g} / \mathrm{l} \mathrm{EMB})$. The latter were sublethal to strain IoA-02, allowing studies of transcript expression, but as expected lethal to IoA-00 (data not shown), with no surviving parasites available for expression studies. Compared to transcript levels in control parasites, treatments with both $0.05 \mu \mathrm{g} / \mathrm{l} \mathrm{DM}$ and $25 \mu \mathrm{g} / \mathrm{l}$ EMB caused upregulation of CYP3027H3 in IoA00 adult males and IoA-02 preadult-II females (Figs. 3, 4). Moreover, an increased transcript abundance of CYP3041E2 was observed in IoA-00 preadult-II females after exposure to $25 \mu \mathrm{g} / \mathrm{l} \mathrm{EMB} \mathrm{(Fig.} \mathrm{4).}$

Finally, the effects of the ecdysteroids Ec and 20HEc and the environmental chemical BAP on CYP transcription were investigated in the IoA-02 strain. No significant effects on CYP transcript abundances were observed in the experiment (Additional file 6: Figure S1).

\section{Discussion}

The present report provides the first genome-wide survey of the CYP superfamily in L. salmonis, a parasite causing considerable economic costs in aquaculture [5]. In the North Atlantic, L. salmonis has developed resistance against most chemical control agents [21], including the pyrethroid DM $[19,59]$ and the macrocyclic lactone EMB $[17,60]$. In terrestrial arthropod pests, resistance to pyrethroids [61, 62] and macrocyclic lactones [63, 64] can be based on the enhanced expression of CYPs involved in pesticide metabolism. The present study did not find evidence for altered CYP transcript expression in a multiresistant L. salmonis strain as compared to a drugsusceptible reference strain. However, in both strains, 
Table 1 The Lepeophtheirus salmonis CYP superfamily. CYPs were identified by homology searches in transcriptome (EBI ENA reference ERS237607) and genome assemblies (LSalAtI2s, ensemble.metazoa.org) and annotated following the criteria of the Cytochrome P450 Nomenclature Committee

\begin{tabular}{|c|c|c|c|c|c|c|c|c|c|}
\hline \multicolumn{5}{|c|}{ Lepeophtheirus salmonis CYP sequence } & \multicolumn{5}{|l|}{ Annotation } \\
\hline $\begin{array}{l}\text { P450 } \\
\text { clan }\end{array}$ & CYP name & $\begin{array}{l}\text { Length } \\
\text { (aa) }\end{array}$ & Transcript & Gene & Best BLAST hit & $\begin{array}{l}\text { Accession } \\
\text { number }\end{array}$ & Species & E-value & $\begin{array}{l}\text { Identity } \\
(\%)\end{array}$ \\
\hline CYP2 & CYP18P1 & 527 & HACA01008353 & EMLSAG000000004688 & $\begin{array}{l}\text { Cytochrome } \\
\text { P450 18E1 }\end{array}$ & AKH03496.1 & $\begin{array}{l}\text { Paracy- } \\
\text { clopina } \\
\text { nana }\end{array}$ & $0.00 E+00$ & 53.56 \\
\hline CYP2 & CYP307N1 & 476 & $\begin{array}{l}\text { HACA01014463 } \\
\text { HACA } 01014464^{b}\end{array}$ & EMLSAG00000001150 b & $\begin{array}{l}\text { Cytochrome } \\
\text { P450 307F1 }\end{array}$ & AKH03498.1 & $\begin{array}{l}\text { Paracy- } \\
\text { clopina } \\
\text { nana }\end{array}$ & $5.00 \mathrm{E}-121$ & 45.09 \\
\hline CYP2 & CYP3031C1 & 526 & HACA01022487 ${ }^{a}$ & EMLSAG00000005163 & $\begin{array}{l}\text { Cytochrome } \\
\text { P450 } \\
\text { CYP3031A1 }\end{array}$ & AlL94135.1 & $\begin{array}{l}\text { Tigriopus } \\
\text { japoni- } \\
\text { cus }\end{array}$ & $2.00 E-124$ & 40.00 \\
\hline CYP2 & CYP3038E1 & 548 & HACA0100651 $1^{\mathrm{b}}$ & EMLSAG00000005721 ${ }^{\mathrm{a}}$ & $\begin{array}{l}\text { Cytochrome } \\
\text { P450 } \\
\text { CYP3038B1 }\end{array}$ & APH81379.1 & $\begin{array}{l}\text { Tigriopus } \\
\text { kingse- } \\
\text { jongen- } \\
\text { sis }\end{array}$ & $5.00 E-139$ & 42.09 \\
\hline CYP2 & CYP3041C1 & 490 & HACA01003809a & EMLSAG000000007328 & $\begin{array}{l}\text { Cytochrome } \\
\text { P450 } \\
\text { 3041B1 }\end{array}$ & AKH03506.1 & $\begin{array}{l}\text { Paracy- } \\
\text { clopina } \\
\text { nana }\end{array}$ & $2.00 \mathrm{E}-145$ & 48.92 \\
\hline CYP2 & CYP3041C2 & 480 & $\begin{array}{l}\text { HACA01027076 } \\
\text { HACA01031477 }\end{array}$ & EMLSAG00000002359 a & $\begin{array}{l}\text { Cytochrome } \\
\text { P450 } \\
\text { 3041B1 }\end{array}$ & AKH03506.1 & $\begin{array}{l}\text { Paracy- } \\
\text { clopina } \\
\text { nana }\end{array}$ & $9.00 E-145$ & 46.30 \\
\hline CYP2 & CYP3041D1 & 481 & HACA01029496 & EMLSAG00000007758 & $\begin{array}{l}\text { Cytochrome } \\
\text { P450 } \\
\text { CYP3041A2 }\end{array}$ & AlL94133.1 & $\begin{array}{l}\text { Tigriopus } \\
\text { japoni- } \\
\text { cus }\end{array}$ & $3.00 E-123$ & 42.65 \\
\hline CYP2 & CYP3041E1 & 477 & $\begin{array}{l}\text { HACA01001994; } \\
\text { HACA01011887 }\end{array}$ & $\begin{array}{l}\text { EMLSAG00000007334 } \\
\text { EMLSAG00000007335 } \\
\text { EMLSAG00000011475 }\end{array}$ & $\begin{array}{l}\text { Cytochrome } \\
\text { P450 } \\
\text { CYP3041A2 }\end{array}$ & APH81382.1 & $\begin{array}{l}\text { Tigriopus } \\
\text { kingse- } \\
\text { jongen- } \\
\text { sis }\end{array}$ & $9.00 E-126$ & 40.57 \\
\hline CYP2 & CYP3041E2 & 482 & HACA01000555 & EMLSAG000000006822 & $\begin{array}{l}\text { Cytochrome } \\
\text { P450 } \\
\text { 3041B1 }\end{array}$ & AKH03506.1 & $\begin{array}{l}\text { Paracy- } \\
\text { clopina } \\
\text { nana }\end{array}$ & $2.00 E-118$ & 41.19 \\
\hline CYP3 & CYP3027H1 & 484 & HACA01003852 $2^{a, c}$ & EMLSAG00000010829 & $\begin{array}{r}\text { Cytochrome } \\
\text { P450 3A24 }\end{array}$ & ACO15001.1 & $\begin{array}{l}\text { Caligus } \\
\text { clem- } \\
\text { ensi }\end{array}$ & $0.00 \mathrm{E}+00$ & 65.45 \\
\hline CYP3 & CYP3027H2 & 482 & HACA01014781 & EMLSAG00000009405 & $\begin{array}{r}\text { Cytochrome } \\
\text { P450 3A24 }\end{array}$ & ACO15001.1 & $\begin{array}{l}\text { Caligus } \\
\text { clem- } \\
\text { ensi }\end{array}$ & $0.00 E+00$ & 63.73 \\
\hline CYP3 & CYP3027H3 & 482 & HACA01004583 & EMLSAG000000005269 & $\begin{array}{r}\text { Cytochrome } \\
\text { P450 3A24 }\end{array}$ & ACO15001.1 & $\begin{array}{l}\text { Caligus } \\
\text { clem- } \\
\text { ensi }\end{array}$ & $0.00 \mathrm{E}+00$ & 63.09 \\
\hline CYP3 & CYP3027H4 & 494 & HACA01012946 & EMLSAG00000012088 & $\begin{array}{r}\text { Cytochrome } \\
\text { P450 3A24 }\end{array}$ & ACO15001.1 & $\begin{array}{l}\text { Caligus } \\
\text { clem- } \\
\text { ensi }\end{array}$ & $0.00 \mathrm{E}+00$ & 62.31 \\
\hline CYP3 & $\begin{array}{l}\text { CYP3027H- } \\
\text { fragment1 }\end{array}$ & 197 & - & EMLSAG00000010833 & $\begin{array}{r}\text { Cytochrome } \\
\text { P450 3A24 }\end{array}$ & ACO10681.1 & $\begin{array}{l}\text { Caligus } \\
\text { roger- } \\
\text { cresseyi }\end{array}$ & $5.00 E-33$ & 64.52 \\
\hline CYP3 & $\begin{array}{l}\mathrm{CYP} 3027 \mathrm{H}- \\
\text { fragment2 }\end{array}$ & 87 & - & EMLSAG00000006848 & $\begin{array}{r}\text { Cytochrome } \\
\text { P450 3A24 }\end{array}$ & ACO10681.1 & $\begin{array}{l}\text { Caligus } \\
\text { roger- } \\
\text { cresseyi }\end{array}$ & $7.00 E-26$ & 66.20 \\
\hline CYP3 & CYP3649A1 & 537 & HACA01001887 $7^{a, b}$ & EMLSAG00000004666 b & $\begin{array}{l}\text { Cytochrome } \\
\text { P450 } \\
\text { CYP3025B1 }\end{array}$ & APH81387.1 & $\begin{array}{l}\text { Tigriopus } \\
\text { kingse- } \\
\text { jongen- } \\
\text { sis }\end{array}$ & $3.00 E-111$ & 36.08 \\
\hline CYP3 & CYP3649A2 & 537 & HACA01004064 & EMLSAG00000006058 & $\begin{array}{l}\text { Cytochrome } \\
\text { P450 } \\
\text { CYP3025B1 }\end{array}$ & APH81387.1 & $\begin{array}{l}\text { Tigriopus } \\
\text { kingse- } \\
\text { jongen- } \\
\text { sis }\end{array}$ & $2.00 E-122$ & 36.02 \\
\hline
\end{tabular}


Table 1 (continued)

\begin{tabular}{|c|c|c|c|c|c|c|c|c|c|}
\hline \multicolumn{5}{|c|}{ Lepeophtheirus salmonis CYP sequence } & \multicolumn{5}{|l|}{ Annotation } \\
\hline $\begin{array}{l}\text { P450 } \\
\text { clan }\end{array}$ & CYP name & $\begin{array}{l}\text { Length } \\
\text { (aa) }\end{array}$ & Transcript & Gene & Best BLAST hit & $\begin{array}{l}\text { Accession } \\
\text { number }\end{array}$ & Species & E-value & $\begin{array}{l}\text { Identity } \\
\text { (\%) }\end{array}$ \\
\hline CYP3 & $\begin{array}{l}\text { CYP3649A- } \\
\text { fragment1 }\end{array}$ & 107 & - & EMLSAG00000002804 & $\begin{array}{l}\text { Cytochrome } \\
\text { P450-like } \\
\text { protein } 3\end{array}$ & ADB28828.1 & $\begin{array}{l}\text { Tigriopus } \\
\text { japoni- } \\
\text { cus }\end{array}$ & $1.00 \mathrm{E}-08$ & 41.18 \\
\hline CYP3 & CYP3651A1P & 492 & HACA01014825 & - & $\begin{array}{l}\text { Cytochrome } \\
\text { P450 } \\
\text { CYP3025B1 }\end{array}$ & APH81387.1 & $\begin{array}{l}\text { Tigriopus } \\
\text { kingse- } \\
\text { jongen- } \\
\text { sis }\end{array}$ & $8.00 \mathrm{E}-22$ & 23.72 \\
\hline $\begin{array}{l}\text { Mito- } \\
\text { chon- } \\
\text { drial }\end{array}$ & CYP44M1 & 483 & HACA01005509a & EMLSAG00000008058 & $\begin{array}{l}\text { Cytochrome } \\
\text { P450 } \\
\text { CYP44D1 }\end{array}$ & APH81396.1 & $\begin{array}{l}\text { Tigriopus } \\
\text { kingse- } \\
\text { jongen- } \\
\text { sis }\end{array}$ & $4.00 \mathrm{E}-144$ & 44.05 \\
\hline $\begin{array}{l}\text { Mito- } \\
\text { chon- } \\
\text { drial }\end{array}$ & CYP44M2 & 431 & HACA01005507 $7^{\mathrm{a}, \mathrm{b}}$ & EMLSAG00000008058 & $\begin{array}{l}\text { Cytochrome } \\
\text { P450 } \\
\text { CYP44D1 }\end{array}$ & APH81396.1 & $\begin{array}{l}\text { Tigriopus } \\
\text { kingse- } \\
\text { jongen- } \\
\text { sis }\end{array}$ & $7.00 \mathrm{E}-126$ & 44.34 \\
\hline $\begin{array}{l}\text { Mito- } \\
\text { chon- } \\
\text { drial }\end{array}$ & CYP302A1 & 470 & $\begin{array}{l}\text { HACA01015112 } \\
\text { HACA01015113 }\end{array}$ & EMLSAG00000005374 & $\begin{array}{l}\text { Putative } \\
\text { ecdysteroid } \\
\text { 22-hydroxy- } \\
\text { lase }\end{array}$ & EFX63066.1 & $\begin{array}{l}\text { Daphnia } \\
\text { pulex }\end{array}$ & 1.00E-144 & 47.50 \\
\hline $\begin{array}{l}\text { Mito- } \\
\text { chon- } \\
\text { drial }\end{array}$ & CYP314A1 & 527 & HACA01031265 & EMLSAG00000009224 & $\begin{array}{l}\text { Cytochrome } \\
\text { P450 } \\
\text { CYP314A1 }\end{array}$ & AlL94172.1 & $\begin{array}{l}\text { Tigriopus } \\
\text { japoni- } \\
\text { cus }\end{array}$ & $0.00 \mathrm{E}+00$ & 54.46 \\
\hline $\begin{array}{l}\text { Mito- } \\
\text { chon- } \\
\text { drial }\end{array}$ & CYP315E1 & 421 & - & EMLSAG00000003403 & $\begin{array}{l}\text { Cytochrome } \\
\text { P450 315A1 }\end{array}$ & AKH03535.1 & $\begin{array}{l}\text { Paracy- } \\
\text { clopina } \\
\text { nana }\end{array}$ & $6.00 \mathrm{E}-85$ & 38.00 \\
\hline $\begin{array}{l}\text { Mito- } \\
\text { chon- } \\
\text { drial }\end{array}$ & CYP3650A1 & 478 & HACA01009722 & EMLSAG00000005044 & $\begin{array}{l}\text { Cytochrome } \\
\text { P450 } \\
3020 \mathrm{~B} 1\end{array}$ & AKH03536.1 & $\begin{array}{l}\text { Paracy- } \\
\text { clopina } \\
\text { nana }\end{array}$ & 7.00E-95 & 36.75 \\
\hline
\end{tabular}

RT-PCR followed by Sanger sequencing was used to confirm cDNA sequences, which were deposited in GenBank (see Additional file 2: Table S2 for accession numbers)

a Predicted polypeptide length based on this sequence

b Partial sequence

c HACA01003852 contains a one-base deletion disrupting the open reading frame, predicted peptide length according to corrected sequence based on RT-PCR/ sequencing data

d HACA01015113 contains a one-base deletion disrupting the open reading frame, predicted peptide length according to corrected sequence based on RT-PCR/ sequencing data

e Gene model EMLSAG00000003403 is the fusion between a CYP gene and a kinase, probably reflecting an assembly problem. Polypeptide length based on CYP sequence only

certain CYPs were upregulated following sublethal drug exposures.

The eukaryotic CYP superfamily is highly diverse, showing complexity within and between species. Molecular phylogenetic analyses of animal CYPs have identified 11 deep-branching clades called CYP clans [29], ten of which emerged early in metazoan evolution [65]. Clan losses occurred in the lineage leading to insects, in which the CYP superfamily is composed of four clans (mitochondrial, CYP2, CYP3 and CYP4). The 25 putative CYP genes/pseudogenes identified in L. salmonis in this study could be unequivocally assigned to the mitochondrial, CYP2 and CYP3 clans, which are also present in other crustaceans such as the branchiopod D. pulex [51], isopods [66] and the copepods T. japonicus and P. nana $[49,50]$. However, while $L$. salmonis and $P$. nana show an apparent lack of CYP4, this clan is present in other crustaceans $[49,51,66]$. Moreover, the free-living copepods T. japonicus and $P$. nana possess CYP20 genes, with $P$. nana additionally having one CYP26 clan gene [49, 50]. The CYP20 and CYP26 clans are present in cnidarians [65], suggesting their emergence prior to the divergence of bilaterians. CYP20 and CYP26 genes have been retained in chordates and lophotrochozoans [67], as well as some arthropods such as chelicerates and myriapods [66], but were lost in lineages leading to insects and most crustacean groups.

The CYP superfamily includes genes that can be classified as environmental response genes [68], as they encode proteins involved in interactions external to the organism. Examples are the CYPs involved in pesticide resistance, which show characteristic traits of environmental 

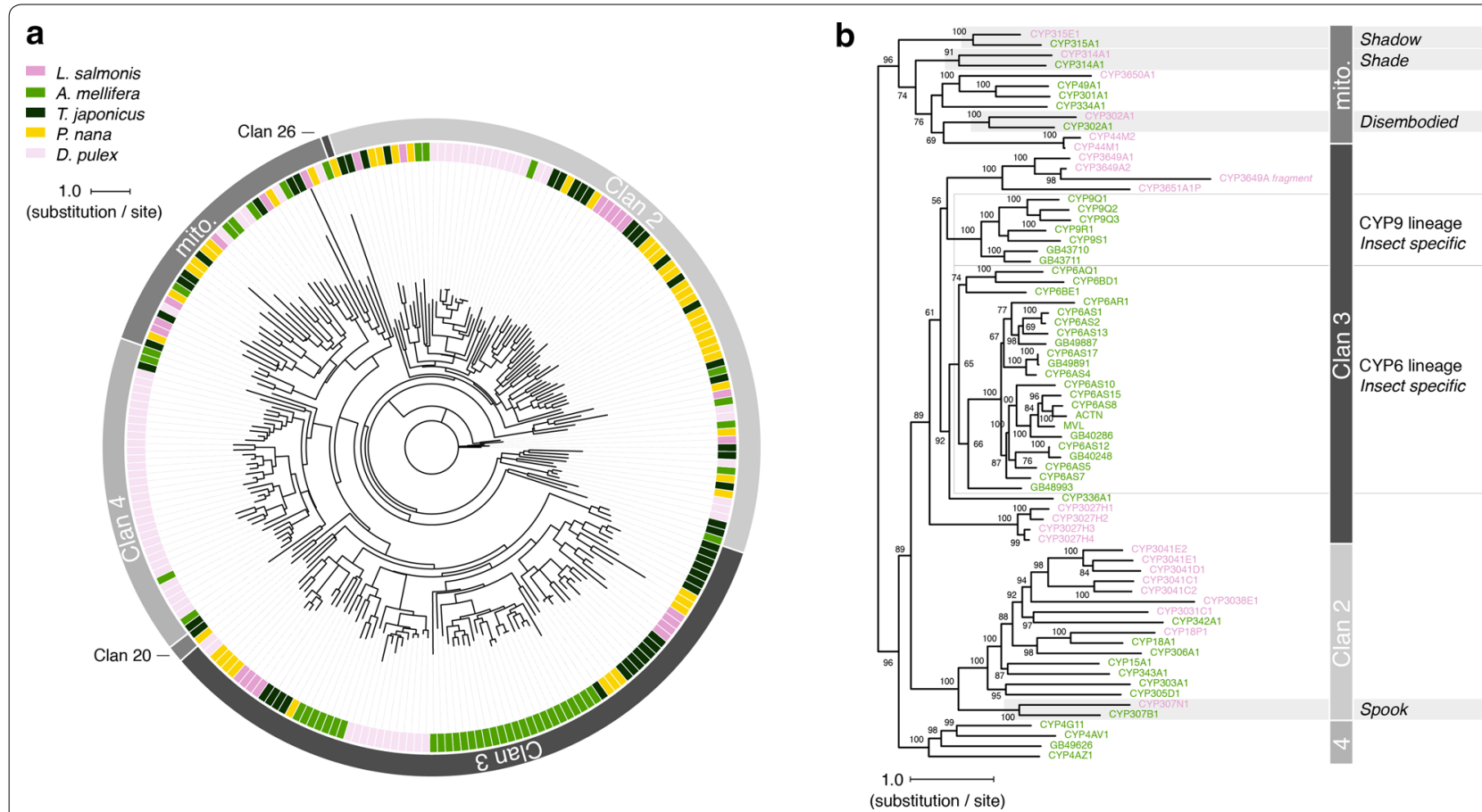

Fig. 1 Phylogenetic analysis of 22 L. salmonis CYPs. Peptide sequences were aligned using the programme GramAlign v3.0 [54] and analysed using IQ-TREE v1.6.9 [55]. a Phylogenetic tree of CYPs from L. salmonis and four arthropod species (Daphnia pulex, Tigriopus japonicus, Paracyclopina nana and Apis mellifera). $\mathbf{b}$ Phylogenetic tree of CYPs from L. salmonis and A. mellifera. Numbers at the branching points of nodes represent percent bootstrap support values

response genes such high diversity, frequent expansion by duplication events and fast rates of evolution [69]. In contrast, CYPs involved in the biosynthesis of endogenous compounds such as hormones commonly show conservation between species. In insects, members of the CYP15 family encode epoxidases involved in juvenile hormone biosynthesis, with some differences between insect orders regarding the late steps of juvenile hormone biosynthesis and the chemical identity of the principal juvenile hormone [70]. In crustaceans, juvenile hormone biosynthesis lacks an epoxidation step and methyl farnesoate performs a similar role to juvenile hormone [71]. The failure to identify CYP15 members in L. salmonis (this study) is in line with the absence of this CYP family in crustaceans studied so far, such as D. pulex [51], T. japonicus, P. nana $[49,50]$ and Neocaridina articulata [72].

Ecdysteroids are key arthropod hormones with a variety of physiological roles, including the regulation of moulting [73, 74]. In insects and crustaceans, the most important ecdysteroids are Ec and 20HEc. The biosynthesis of these ecdysteroids involves a set of CYPs called the Halloween genes, originally identified in fruit fly [32]. After the conversion of cholesterol of dietary origin to 7-dehydrocholesterol by the Rieske-like oxygenase neverland, halloween genes catalyse the remaining steps of ecdysteroid biosynthesis. The first of these steps, still poorly understood and referred to as "black box" reactions, involves two CYP307 family paralogues in Drosophila, spook (CYP307A1) and spookier CYP307A2. Other insects may possess a further paralogue, spookiest (CYP307B1) believed to have a similar role. The remaining Halloween genes, phantom (CYP306A1), disembodied (CYP302A1) and shadow (CYP315A1) and shade (CYP314A1) are hydroxylases modifying the ecdysteroid at the 25-, 22-, 2- and 20-positions, respectively. Further related to ecdysteroid metabolism is CYP18A1 [75], a 26-hydroxylase inactivating the bioactive steroid 20-hydroxyecdysone.

Lepeophtheirus salmonis orthologues of neverland, disembodied and shade have recently been reported and characterised regarding their tissue distribution [76]. The present study further identified putative $L$. salmonis homologues of spook/spookier (CYP307A1/2), shadow (CYP315A1) and a CYP18A1 homologue. The failure of genome and transcriptome scans of this study to identify a $L$. salmonis homologue of phantom could be either due to absence of this gene in L. salmonis, or lack of its representation in current sequence repositories. Phantom is lacking in chelicerates [71], in which ponasterone A (25-deoxy-20-hydroxyecdysone) likely represents the bioactive ecdysteroid [77]. Arguing against a lack of phantom in L. salmonis, Ec, 20HEc and ponasterone A 


\begin{tabular}{|c|c|c|c|c|c|c|c|c|}
\hline \multirow[t]{2}{*}{ CYP clan } & \multirow[t]{2}{*}{ Gene } & \multicolumn{2}{|c|}{ Female/Preadult- } & \multicolumn{2}{|c|}{ Male/Adult } & \multicolumn{3}{|c|}{ P-values } \\
\hline & & IoA-00 & IoA-02 & IoA-00 & IoA-02 & Strain & Sex/Stage & Strain*Sex/Stage \\
\hline \multirow[t]{9}{*}{ Clan 2} & CYP18P1 & 0.78 & 1.38 & 0.85 & 0.99 & 0.02824 & 0.32635 & 0.86249 \\
\hline & CYP307N1 & 1.08 & 0.92 & 0.87 & 1.13 & 0.48842 & 0.95396 & 0.02434 \\
\hline & CYP3031C1 & 0.45 & 0.66 & 1.39 & 1.50 & 0.41892 & 0.00014 & 0.56370 \\
\hline & CYP3038E1 & 0.15 & 0.31 & 1.77 & 1.77 & 0.24821 & 0.00003 & 0.35561 \\
\hline & CYP3041C1 & 0.58 & 1.03 & 1.33 & 1.06 & 0.29870 & 0.08327 & 0.08327 \\
\hline & CYP3041C2 & 0.58 & 0.87 & 1.30 & 1.25 & 0.45292 & 0.01107 & 0.32635 \\
\hline & CYP3041D1 & 0.80 & 1.06 & 1.00 & 1.13 & 0.01304 & 0.41892 & 0.45292 \\
\hline & CYP3041E1 & 1.13 & 1.18 & 0.77 & 0.91 & 0.70739 & 0.90805 & 0.43563 \\
\hline & CYP3041E2 & 0.28 & 0.35 & 1.41 & 1.95 & 0.48842 & 0.00004 & 0.77283 \\
\hline \multirow[t]{7}{*}{ Clan 3} & CYP3027H1 & 0.88 & 0.75 & 1.09 & 1.27 & 0.81736 & 0.00558 & 0.24821 \\
\hline & CYP3027H2 & 0.31 & 0.37 & 1.57 & 1.75 & 0.68611 & 0.00003 & 0.95396 \\
\hline & СYР3027H3 & 0.46 & 0.30 & 1.37 & 1.88 & 0.90807 & 0.00003 & 0.16586 \\
\hline & CYP3027H4 & 0.29 & 0.57 & 1.23 & 1.91 & 0.13333 & 0.00017 & 0.95396 \\
\hline & CYP3649A1 & 0.11 & 0.55 & 1.47 & 1.87 & 0.09407 & 0.00011 & 0.56370 \\
\hline & CYP3649A2 & 0.44 & 0.41 & 1.63 & 1.53 & 0.90807 & 0.00005 & 0.81736 \\
\hline & CYP3651A1P & 0.87 & 1.07 & 1.16 & 0.90 & 0.60333 & 0.48842 & 0.38648 \\
\hline Mitochondria & CYP44M1 & 1.60 & 1.25 & 0.42 & 0.72 & 0.72903 & 0.00004 & 0.09407 \\
\hline \multirow[t]{4}{*}{ Clan } & CYP44M2 & 1.55 & 1.39 & 0.43 & 0.62 & 0.81736 & 0.00003 & 0.48842 \\
\hline & CYP302A1 & 0.59 & 1.18 & 0.98 & 1.25 & 0.00389 & 0.14892 & 0.27266 \\
\hline & CYP314A1 & 2.08 & 1.17 & 0.32 & 0.43 & 0.38648 & 0.27266 & 0.64417 \\
\hline & CYP3650A1 & 0.76 & 0.85 & 1.07 & 1.32 & 0.27266 & 0.00182 & 0.68611 \\
\hline $\begin{array}{l}\text { Fig. } 2 \text { CYP transcri } \\
\text { adult males of two } \\
\text { is expressed as fold } \\
\text { below average exp } \\
P \text {-values significant }\end{array}$ & $\begin{array}{l}\text { expression in tv } \\
\text { salmonis strains } \\
\text { kpression comp } \\
\text { ssion in red. Effe } \\
\text { ter Bonferroni c }\end{array}$ & $\begin{array}{l}\text { almonis str } \\
0 \text { : drug-su } \\
\text { the avera } \\
\text { strain, sex/ } \\
\text { on are giv }\end{array}$ & $\begin{array}{l}\text { Transcript } \\
\text { ible, loA-c } \\
\text { kpression } \\
\text { and inter } \\
\text { bold prin }\end{array}$ & $\begin{array}{l}\text { oression } \\
\text { multi-re } \\
\text { ong all } \\
\text { ion of s }\end{array}$ & $\begin{array}{l}\text { YPs was } \\
\text { t). The } \\
\text { os, with } \\
\text { and sex }\end{array}$ & $\begin{array}{l}\text { mined by } \\
\text { pt abunda } \\
\text { average ex } \\
\text { were asse }\end{array}$ & $\begin{array}{l}\text { PCR in prea } \\
\text { in the reley } \\
\text { ssion highli } \\
\text { by the Sch }\end{array}$ & $\begin{array}{l}\text { t-II females and } \\
\text { t stage and strain } \\
\text { ted in green and } \\
\text { er-Ray-Hare test. }\end{array}$ \\
\hline
\end{tabular}

have been reported in larval and female adult stages of the parasite [76], with the biosynthesis of the former two hormones requiring 25-hydroxylase activity [78].

Compared to the number of CYP genes in free-living crustaceans, e.g. 75 in the phyllopod D. pulex [51] and 52 and 46 in the non-parasitic copepods T. japonicus and $P$. nana $[49,50]$, respectively, the $L$. salmonis CYP superfamily appears very small. A reduction in the size of gene superfamilies with roles in the biochemical defence against xenobiotics has previously been reported from insect ectoparasites lacking free-living stages, such as the human body louse (37 CYPs), compared to non-parasitic insects such as the fruit fly (85 CYPs) or ectoparasites possessing free-living life stages such as mosquitoes (204 CYPs) $[30,79]$. Direct exposure to environmental toxins for such species may be reduced as a result of their parasitic lifestyle, with biochemical detoxification pathways of the host providing further protection. Supporting this hypothesis, previous studies of the $A B C$ (ATP-binding cassette) gene family, which encodes membrane transporters many of which function in the detoxification of xenobiotics and endogenous compounds, found that $L$. salmonis possesses only $33 \mathrm{ABC}$ genes [48], compared to 64 members of this gene superfamily in $D$. pulex [80].

In the present study, 11 of 21 studied CYPs differed significantly in transcript expression between preadultII females and adult males. These stages were selected for study as they appear at the same time in synchronised cohorts of developing parasites and have approximately the same size and are well defined physiologically, whereas the large adult females undergo significant postmoulting growth and cycles of egg production and vitellogenesis [81], making this stage heterogeneous. While the moulting cycle can strongly affect CYP expression in crustaceans $[82,83]$, as can be expected for CYPs involved in ecdysteroid biosynthesis and metabolism, $L$. salmonis halloween genes and CYP18P1 were not found to be differentially expressed between preadult-II females and adult males in this study. Sex-biased transcript expression of CYPs in L. salmonis has previously been described from a microarray study, which included 12 CYPs, of which six showed sex-biased transcription [84]. 


\begin{tabular}{|c|c|c|c|c|c|c|c|}
\hline \multirow[t]{3}{*}{ CYP clan } & \multirow[t]{4}{*}{ Gene } & \multicolumn{3}{|c|}{ Female/Preadult-II } & \multicolumn{3}{|c|}{ Male/Adult } \\
\hline & & \multirow{3}{*}{$\begin{array}{l}\text { Strain } \\
\text { IoA-00 } \\
\text { DM0.05 }\end{array}$} & \multirow{2}{*}{\multicolumn{2}{|c|}{$\begin{array}{l}\text { Strain } \\
\text { loA-02 }\end{array}$}} & \multirow{3}{*}{$\begin{array}{c}\text { Strain } \\
\text { IoA-00 } \\
\text { DM0.05 }\end{array}$} & \multirow{2}{*}{\multicolumn{2}{|c|}{$\begin{array}{l}\text { Strain } \\
\text { loA-02 }\end{array}$}} \\
\hline & & & & & & & \\
\hline \multirow{10}{*}{ Clan 2} & & & DM0.05 & DM2.00 & & DM0.05 & DM2.00 \\
\hline & CYP18P1 & 1.85 & 1.07 & 0.59 & 1.31 & 1.62 & 0.83 \\
\hline & CYP307N1 & $\star \star 0.70$ & 0.87 & 1.07 & 1.01 & 0.97 & 1.17 \\
\hline & CYP3031C1 & 1.38 & 1.15 & 1.00 & 1.24 & 0.94 & 0.91 \\
\hline & CYP3038E1 & 1.74 & 1.08 & 1.37 & 0.80 & 1.55 & 1.83 \\
\hline & CYP3041C1 & 1.73 & 1.36 & 0.88 & 1.73 & 1.34 & 1.23 \\
\hline & CYP3041C2 & 1.37 & 1.25 & 0.78 & 1.54 & 1.17 & 1.16 \\
\hline & CYP3041D1 & 1.10 & 1.07 & 0.74 & 1.25 & 1.04 & 1.03 \\
\hline & CYP3041E1 & 2.10 & 1.29 & 1.87 & 0.83 & 1.24 & 0.80 \\
\hline & CYP3041E2 & 1.60 & 1.70 & *2.34 & 1.50 & 1.57 & *2.36 \\
\hline \multirow[t]{7}{*}{ Clan 3} & CYP3027H1 & 0.87 & 1.35 & 1.24 & 0.85 & 1.14 & 1.05 \\
\hline & CYP3027H2 & 1.12 & 1.24 & 1.19 & 1.35 & 1.18 & 1.15 \\
\hline & СYP3027H3 & 1.36 & $\star \star 2.95$ & 0.74 & $\star \star \star * 3.04$ & 1.41 & 0.65 \\
\hline & CYP3027H4 & 1.01 & 1.24 & 0.47 & 1.15 & 0.72 & 1.01 \\
\hline & CYP3649A1 & $\star \star 3.50$ & 1.32 & $\star 0.22$ & 1.18 & 0.97 & *0.48 \\
\hline & CYP3649A2 & 1.19 & 0.89 & 0.91 & 0.95 & 1.14 & 0.84 \\
\hline & CYP3651A1P & 1.12 & 0.98 & 1.02 & *0.62 & 1.28 & 1.66 \\
\hline \multirow{5}{*}{$\begin{array}{l}\text { Mitochondrial } \\
\text { clan }\end{array}$} & CYP44M1 & 0.92 & 0.92 & 1.29 & *1.44 & 0.92 & 1.00 \\
\hline & CYP44M2 & 1.04 & 1.07 & 1.03 & 1.42 & 1.18 & 1.14 \\
\hline & CYP302A1 & 1.40 & 1.04 & 0.98 & 0.73 & 1.23 & 0.88 \\
\hline & CYP314A1 & 1.12 & 1.05 & 2.23 & 1.47 & 0.93 & 0.88 \\
\hline & CYP3650A1 & $\star 1.63$ & 1.33 & 1.26 & *1.39 & 1.16 & 1.08 \\
\hline \multicolumn{8}{|c|}{ 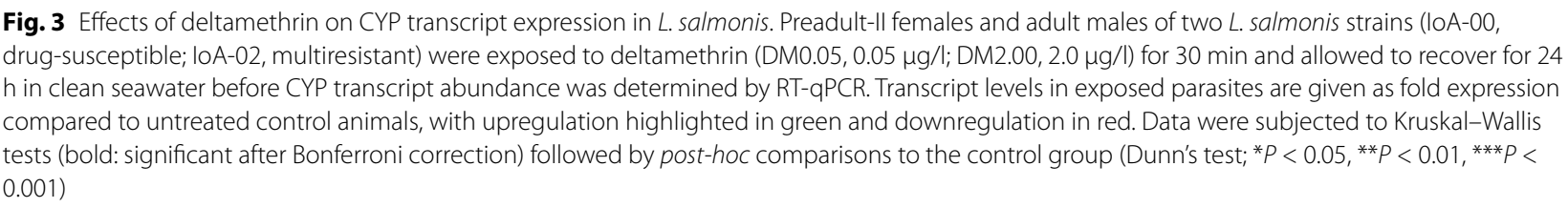 } \\
\hline
\end{tabular}

In the present study, differences in CYP transcript expression between the multiresistant strain IoA-02 and the drug-susceptible reference strain IoA-00 were not significant. However, exposure to both DM and EMB caused significant transcriptional upregulation of CYP3027H3 in IoA-02 females and IoA-00 males, with EMB exposure further increasing CYP3041E2 transcription in IoA-00 females. In a previous microarray study [46], effects of the pyrethroid cypermethrin on transcript expression in L. salmonis copepodids included 3.8-fold upregulation of CYP3027H4 (referred to as "CYP3A24", GenBank: JP326960.1) and 5.3- to 7.9-fold upregulation of CYP3649A2 (represented twice and referred to as "CYP6w1" or "CYP6d4", GenBank: JP317875.1 and JP334550.1). Moreover, transcripts of CYP3031C1 and CYP3041C2, referred to by BLAST annotations as
"CYP18A1" and "CYP15A1", have been found to be constitutively overexpressed in an EMB resistant $L$. salmonis strain in an earlier microarray study [45]. Taken together, the data from this study and previous microarray studies suggest that a number of $L$. salmonis CYPs, particularly in clans CYP2 and CYP3, have roles as environmental response genes. Support for such roles of the CYP3027 family is provided by studies with free-living copepods T. japonicus [49] and P. nana [50], in which members of families CYP3027 and CYP2024 were transcriptionally upregulated following crude oil exposure. Interestingly, signature sequences typical for genes with roles in the detoxification of chemicals, such as aryl hydrocarbon responsive elements, xenobiotic responsive elements and metal response elements, were found in the promotor regions of oil-responsive T. japonicus CYPs [49]. 


\begin{tabular}{|c|c|c|c|c|c|c|c|}
\hline \multirow[t]{4}{*}{ CYP clan } & \multirow[t]{4}{*}{ Gene } & \multicolumn{3}{|c|}{ Female/Preadult-II } & \multicolumn{3}{|c|}{ Male/Adult } \\
\hline & & \multirow{3}{*}{$\begin{array}{l}\text { Strain } \\
\text { IoA-00 } \\
\text { DM0.05 }\end{array}$} & \multirow{2}{*}{\multicolumn{2}{|c|}{$\begin{array}{l}\text { Strain } \\
\text { IoA-02 }\end{array}$}} & \multirow{3}{*}{$\begin{array}{l}\text { Strain } \\
\text { IoA-00 } \\
\text { DM0.05 }\end{array}$} & \multirow{2}{*}{\multicolumn{2}{|c|}{$\begin{array}{l}\text { Strain } \\
\text { IOA-02 }\end{array}$}} \\
\hline & & & & & & & \\
\hline & & & DM0.05 & DM2.00 & & DM0.05 & DM2.00 \\
\hline \multirow[t]{9}{*}{ Clan 2} & CYP18P1 & EMB25 & EMB25 & EMB150 & EMB25 & EMB25 & EMB150 \\
\hline & CYP307N1 & **3.97 & 0.79 & 1.68 & 2.09 & 1.22 & 1.11 \\
\hline & CYP3031C1 & **0.77 & 0.76 & 0.87 & 0.92 & 1.93 & 0.77 \\
\hline & CYP3038E1 & 1.56 & 1.17 & 1.41 & 1.03 & 1.48 & 1.16 \\
\hline & CYP3041C1 & *2.52 & 1.23 & 1.64 & 0.68 & 2.13 & 1.28 \\
\hline & CYP3041C2 & $\star * 2.37$ & 1.29 & 1.26 & 1.51 & 1.29 & 1.81 \\
\hline & CYP3041D1 & 1.53 & 1.12 & 1.37 & 1.11 & 1.11 & 1.25 \\
\hline & CYP3041E1 & 1.40 & 0.95 & 1.10 & 1.06 & 0.92 & 0.86 \\
\hline & CYP3041E2 & 0.97 & 0.64 & 0.64 & 1.34 & 1.65 & 1.21 \\
\hline \multirow[t]{7}{*}{ Clan 3} & CYP3027H1 & $\star \star \star 2.34$ & *2.50 & $* * 2.60$ & 1.21 & *1.92 & 1.72 \\
\hline & CYP3027H2 & 0.94 & 0.82 & 1.11 & 1.05 & 1.33 & 1.47 \\
\hline & СYP3027H3 & 1.11 & 1.29 & 1.25 & 1.06 & 1.11 & 0.97 \\
\hline & CYP3027H4 & 1.45 & $\star 2.33$ & 1.38 & $\star \star \star 2.26$ & 1.54 & 1.12 \\
\hline & CYP3649A1 & 1.09 & 0.66 & 0.65 & 1.37 & 0.78 & 0.65 \\
\hline & CYP3649A2 & **3.66 & 0.98 & 1.17 & 0.82 & 0.94 & 0.70 \\
\hline & CYP3651A1P & 1.30 & 1.15 & 1.19 & 1.07 & 0.91 & 0.92 \\
\hline \multirow{5}{*}{$\begin{array}{l}\text { Mitochondrial } \\
\text { clan }\end{array}$} & CYP44M1 & 1.29 & 1.09 & 1.67 & 0.79 & 1.57 & 1.26 \\
\hline & CYP44M2 & 0.76 & 0.89 & 1.17 & *1.54 & 0.65 & 0.94 \\
\hline & CYP302A1 & 1.18 & 1.04 & 1.19 & $\star \star 1.78$ & 1.10 & 1.17 \\
\hline & CYP314A1 & *1.63 & 0.94 & 1.07 & 0.70 & 1.16 & 0.71 \\
\hline & CYP3650A1 & 0.40 & 0.95 & 1.20 & 2.05 & 0.75 & 1.35 \\
\hline \multicolumn{8}{|c|}{$\begin{array}{l}\text { Fig. } 4 \text { Effects of emamectin benzoate (EMB) on CYP transcript expression in L. salmonis. Preadult-ll females and adult males of two L. salmonis } \\
\text { strains (IOA-00, drug-susceptible; loA-02, multiresistant) were exposed to emamectin benzoate (EMB25, } 25 \mathrm{\mu g} / / \text {; EMB150, } 150 \mathrm{\mu g} / \mathrm{l} \text { ) for } 24 \mathrm{~h} \text { before } \\
\text { CYP transcript abundance was determined by RT-qPCR. Transcript levels in exposed parasites are given as fold expression compared to untreated } \\
\text { control animals, with upregulation highlighted in green and downregulation in red. Data were subjected to Kruskal-Wallis tests (bold: significant } \\
\text { after Bonferroni correction) followed by post-hoc comparisons to the control group (Dunn's test; }{ }^{*} P<0.05 \text {, }{ }^{* * P}<0.01 \text {, }{ }^{* * * P}<0.001 \text { ) }\end{array}$} \\
\hline
\end{tabular}

\section{Conclusions}

The CYP superfamily of $L$. salmonis is the smallest of all arthropods characterised to date. Lepeophtheirus salmonis CYPs include conserved genes involved in ecdysteroid biosynthesis and metabolism, as well as drug-inducible genes. In the parasite strains studied, no evidence was found for a role of CYP genes in mediating drug resistance.

\section{Supplementary information}

Supplementary information accompanies this paper at https://doi. org/10.1186/s13071-019-3808-x.

Additional file 1: Table S1. Accession numbers of arthropod CYPs.

Additional file 2: Table S2. Oligonucleotide primer sequences used in RT-PCR and sequencing experiments.
Additional file 3: Table S3. Oligonucleotide primer sequences used in RT-qPCR experiments.

Additional file 4: Table S4. Susceptibility of $L$. salmonis strains to salmon delousing agents.

Additional file 5: Table S5. Conserved motifs in L. salmonis CYP predicted amino acid sequences.

Additional file 6: Figure S1. Effects of ecdysteroids and benzo[a]pyrene on L. salmonis CYP transcript expression.

\section{Abbreviations}

CYP: cytochrome P450; PCR: polymerase chain reaction; RT-PCR: reverse transcription PCR; RT-qPCR: quantitative RT-PCR; IPM: integrated pest management; DDT: dichlorodiphenyltrichloroethane; $\mathrm{EC}_{50}$ : median effective concentration; EMB: emamectin benzoate; DM: deltamethrin; Ec: ecdysone; 20HEc: 20-hydroxyecdysone; BaP: benzo[a] pyrene; PEG: polyethylene glycol; Mn: number average molar mass; EDTA: ethylenediaminetetraacetic acid; cDNA: complementary DNA. 


\section{Acknowledgements}

The authors thank Ketil Malde and Rasmus Skern of the Salmon Louse Genome Project for granting us access to the L. salmonis genome assembly LSalAtI2s prior to its publication on metazoan.ensemble.org and the Fish Vet Group, Inverness, UK, for a sample of Salmosan Vet ${ }^{\circledR} 500$.

\section{Authors' contributions}

Design of study: JLH, MB and AS. Homology searches and phylogenetic analyses: JLH, GCA, MB, CMM and AS. RT-PCR and Sanger sequencing: JLH, GCA and CMM. Bioassays, chemical exposures, RNA extractions and RT-qPCR experiments: JLH, GCA, IE and DIB. Data analysis: AS, GCA and MB. Principal manuscript authors: AS and JLH, with further contributions from all participating researchers. All authors read and approved the final manuscript.

\section{Funding}

This study was supported by United Kingdom Biotechnology and Biological Sciences Research Council grant BB/L022923/1 awarded to AS. The authors are further thankful to the Scottish Salmon Producers' Organisation for financial support and gratefully acknowledge funding received from the MASTS pooling initiative (The Marine Alliance for Science and Technology for Scotland). MASTS is funded by the Scottish Funding Council (grant reference HR09011) and contributing institutions. The funders had no role in study design, data collection and analyses, decision to publish, or preparation of the manuscript.

\section{Availability of data and materials}

The raw datasets for RT-qPCR analyses and bioassays used in the present study are available from the corresponding author upon request. All other data generated or analysed during this study are included in this published article and its additional files.

\section{Ethics approval and consent to participate}

All research projects involving the University of Stirling (UoS) are subject to a thorough Ethical Review Process prior to any work being approved. All projects with UoS participation are required to be submitted to the UoS Animal Welfare Ethical Review Body (AWERB) for approval, irrespective of where experimentation will be carried out. This procedure ensures all ethical issues are addressed before an experiment can be initiated. The present research was assessed by the UOS AWERB and passed the ethical review process. Laboratory infections of Atlantic salmon with L. salmonis were carried out under a valid UK Home Office project license.

\section{Consent for publication}

Not applicable.

\section{Competing interests}

The authors declare that they have no competing interests.

\section{Author details}

${ }^{1}$ Institute of Aquaculture, University of Stirling, Stirling FK9 4LA, Scotland, UK

${ }^{2}$ Department of Microbiology, University of Tennessee, Memphis, TN 38163 , USA.

Received: 28 July 2019 Accepted: 15 November 2019

Published online: 27 November 2019

\section{References}

1. Boxaspen K. A review of the biology and genetics of sea lice. ICES J Mar Sci. 2006;63:1304-16.

2. Skern-Mauritzen R, Torrissen O, Glover KA. Pacific and Atlantic Lepeophtheirus salmonis (Krøyer, 1838) are allopatric subspecies: Lepeophtheirus salmonis salmonis and L. salmonis oncorhynchi subspecies novo. BMC Genet. 2014;15:32.

3. Wagner GN, Fast MD, Johnson SC. Physiology and immunology of Lepeophtheirus salmonis infections of salmonids. Trends Parasitol. 2008;24:176-83.

4. Torrissen O, Jones S, Asche F, Guttormsen A, Skilbrei OT, Nilsen F, et al. Salmon lice_-impact on wild salmonids and salmon aquaculture. J Fish Dis. 2013:36:171-94.
5. Brooker AJ, Skern-Mauritzen R, Bron JE. Production, mortality, and infectivity of planktonic larval sea lice, Lepeophtheirus salmonis (Krøyer, 1837): current knowledge and implications for epidemiological modelling. ICES J Mar Sci. 2018;75:1214-34.

6. Jackson D, Cotter D, Newell J, McEvoy S, O'Donohoe P, Kane F, et al. Impact of Lepeophtheirus salmonis infestations on migrating Atlantic salmon, Salmo salar L, smolts at eight locations in Ireland with an analysis of lice-induced marine mortality. J Fish Dis. 2013;36:273-81.

7. Sayer MDJ, Treasurer JW, Costello MJ, editors. Wrasse: biology and use in aquaculture. Oxford: Wiley-Blackwell; 1996.

8. Skiftesvik AB, Blom G, Agnalt A-L, Durif CMF, Browman HI, Bjelland RM, et al. Wrasse (Labridae) as cleaner fish in salmonid aquaculture-the Hardangerfjord as a case study. Mar Biol Res. 2014;10:289-300.

9. Stien LH, Dempster T, Bui S, Glaropoulos A, Fosseidengen JE, Wright DW, et al. "Snorkel" sea lice barrier technology reduces sea lice loads on harvest-sized Atlantic salmon with minimal welfare impacts. Aquaculture. 2016:458:29-37.

10. Sutherland BJG, Covello JM, Friend SE, Poley JD, Koczka KW. Host-parasite transcriptomics during immunostimulant-enhanced rejection of salmon lice (Lepeophtheirus salmonis) by Atlantic salmon (Salmo salar). Facets. 2017:2:477-95

11. Ljungfeldt LER, Quintela M, Besnier F, Nilsen F, Glover KA. A pedigreebased experiment reveals variation in salinity and thermal tolerance in the salmon louse, Lepeophtheirus salmonis. Evol Appl. 2017;10:1007-19.

12. Burridge L, Weis JS, Cabello F, Pizarro J, Bostick K. Chemical use in salmon aquaculture: a review of current practices and possible environmental effects. Aquaculture. 2010;306:7-23.

13. Denholm I, Devine GJ, Horsberg TE, Sevatdal S, Fallang A, Nolan DV, et al. Analysis and management of resistance to chemotherapeutants in salmon lice, Lepeophtheirus salmonis (Copepoda: Caligidae). Pest Manag Sci. 2002;58:528-36.

14. Roth M, Richards RH, Dobson DP, Rae GH. Field trials on the efficacy of the organophosphorus compound azamethiphos for the control of sea lice (Copepoda: Caligidae) infestations of farmed Atlantic salmon (Salmo salar). Aquaculture. 1996;140:217-39.

15. Sevatdal S, Copley L, Wallace C, Jackson D, Horsberg TE. Monitoring of the sensitivity of sea lice (Lepeophtheirus salmonis) to pyrethroids in Norway, Ireland and Scotland using bioassays and probit modelling. Aquaculture. 2005;244:19-27.

16. Treasurer JW, Wadsworth S, Grant A. Resistance of sea lice, Lepeophtheirus salmonis (Krøyer), to hydrogen peroxide on farmed Atlantic salmon, Salmo salar L. Aquac Res. 2000;31:855-60.

17. Heumann J, Carmichael S, Bron JE, Tildesley A, Sturm A. Molecular cloning and characterisation of a novel P-glycoprotein in the salmon louse Lepeophtheirus salmonis. Comp Biochem Physiol C Toxicol Pharmacol. 2012;155:198-205.

18. Kaur K, Helgesen KO, Bakke MJ, Horsberg TE. Mechanism behind resistance against the organophosphate azamethiphos in salmon lice (Lepeophtheirus salmonis). PLoS One. 2015:10:e0124220.

19. Carmona-Antoñanzas G, Bekaert M, Humble JH, Boyd S, Roy W, Bassett $\mathrm{DI}$, et al. Maternal inheritance of deltamethrin resistance in the salmon louse Lepeophtheirus salmonis (Krøyer) is associated with unique mtDNA haplotypes. PLoS ONE. 2017:12:e0180625.

20. Carmona-Antoñanzas G, Helgesen KO, Humble JL, Tschesche C, Bakke MJ, Gamble L, et al. Mutations in voltage-gated sodium channels from pyrethroid resistant salmon lice (Lepeophtheirus salmonis). Pest Manag Sci. 2019:75:527-36.

21. Aaen SM, Helgesen KO, Bakke MJ, Kaur K, Horsberg TE. Drug resistance in sea lice: a threat to salmonid aquaculture. Trends Parasitol. 2015;31:72-81.

22. Heckel DG. Ecology. Insecticide resistance after Silent Spring. Science. 2012;337:1612-4

23. French-Constant $\mathrm{RH}$, Rocheleau TA, Steichen JC, Chalmers AE. A point mutation in a Drosophila GABA receptor confers insecticide resistance. Nature 1993:363:449-51.

24. Williamson MS, Martinez-Torres D, Hick CA, Devonshire AL. Identification of mutations in the housefly para-type sodium channel gene associated with knockdown resistance (kdr) to pyrethroid insecticides. Mol Gen Genet. 1996:252:51-60 
25. Ranson H, Claudianos C, Ortelli F, Abgrall C, Hemingway J, Sharakhova $\mathrm{MV}$, et al. Evolution of supergene families associated with insecticide resistance. Science. 2002;298:179-81.

26. Helgesen $\mathrm{KO}$, Bakke MJ, Kaur K, Horsberg TE. Increased catalase activitya possible resistance mechanism in hydrogen peroxide resistant salmon lice (Lepeophtheirus salmonis). Aquaculture. 2017;468:135-40.

27. Besnier F, Kent M, Skern-Mauritzen R, Lien S, Malde K, Edvardsen RB, et al. Human-induced evolution caught in action: SNP-array reveals rapid amphi-atlantic spread of pesticide resistance in the salmon ecotoparasite Lepeophtheirus salmonis. BMC Genomics. 2014;15:937.

28. Nelson DR. Progress in tracing the evolutionary paths of cytochrome P450. Biochim Biophys Acta. 2011;1814:14-8.

29. Nelson DR. Metazoan cytochrome P450 evolution. Comp Biochem Physiol C Pharmacol Toxicol Endocrinol. 1998;121:15-22.

30. Lee SH, Kang JS, Min JS, Yoon KS, Strycharz JP, Johnson R, et al. Decreased detoxification genes and genome size make the human body louse an efficient model to study xenobiotic metabolism. Insect Mol Biol. 2010;19:599-615.

31. Gulia-Nuss M, Nuss AB, Meyer JM, Sonenshine DE, Roe RM, Waterhouse RM, et al. Genomic insights into the Ixodes scapularis tick vector of Lyme disease. Nat Commun. 2016;7:10507.

32. Rewitz KF, O'Connor MB, Gilbert LI. Molecular evolution of the insect Halloween family of cytochrome P450s: phylogeny, gene organization and functional conservation. Insect Biochem Mol Biol. 2007;37:741-53.

33. Helvig C, Koener JF, Unnithan GC, Feyereisen R. CYP15A1, the cytochrome P450 that catalyzes epoxidation of methyl farnesoate to juvenile hormone III in cockroach corpora allata. Proc Natl Acad Sci USA 2004;101:4024-9.

34. Qiu Y, Tittiger C, Wicker-Thomas C, Le Goff G, Young S, Wajnberg E, et al. An insect-specific P450 oxidative decarbonylase for cuticular hydrocarbon biosynthesis. Proc Natl Acad Sci USA. 2012;109:14858-63.

35. Feyereisen R. Insect CYP genes and P450 enzymes. In: Gilbert LI, editor. Insect molecular biology and biochemistry. San Diego, CA: Elsevier; 2012. p. $236-316$

36. Tao X-Y, Xue X-Y, Huang Y-P, Chen X-Y, Mao Y-B. Gossypol-enhanced P450 gene pool contributes to cotton bollworm tolerance to a pyrethroid insecticide. Mol Ecol. 2012;21:4371-85

37. Ranson H, N'guessan R, Lines J, Moiroux N, Nkuni Z, Corbel V. Pyrethroid resistance in African anopheline mosquitoes: what are the implications for malaria control? Trends Parasitol. 2011;27:91-8.

38. David J-P, Ismail HM, Chandor-Proust A, Paine MJI. Role of cytochrome P450s in insecticide resistance: impact on the control of mosquito-borne diseases and use of insecticides on Earth. Philos Trans R Soc B Biol Sci. 2013;368:20120429.

39. Daborn PJ, Yen JL, Bogwitz MR, Le Goff G, Feil E, Jeffers S, et al. A single P450 allele associated with insecticide resistance in Drosophila. Science. 2002:297:2253-7.

40. McLaughlin LA, Niazi U, Bibby J, David JP, Vontas J, Hemingway J, et al. Characterization of inhibitors and substrates of Anopheles gambiae CYP6Z2. Insect Mol Biol. 2008;17:125-35.

41. Müller P, Warr E, Stevenson BJ, Pignatelli PM, Morgan JC, Steven A, et al. Field-caught permethrin-resistant Anopheles gambiae overexpress CYP6P3, a P450 that metabolises pyrethroids. PLoS Genet. 2008;4:e1000286.

42. Daborn PJ, Lumb C, Boey A, Wong W, French-Constant RH, Batterham P. Evaluating the insecticide resistance potential of eight Drosophila melanogaster cytochrome P450 genes by transgenic over-expression. Insect Biochem Mol Biol. 2007;37:512-9.

43. Zhu F, Parthasarathy R, Bai H, Woithe K, Kaussmann M, Nauen R, et al. A brain-specific cytochrome $\mathrm{P} 450$ responsible for the majority of deltamethrin resistance in the QTC279 strain of Tribolium castaneum. Proc Natl Acad Sci USA. 2010;107:8557-62.

44. Bautista MAM, Miyata T, Miura K, Tanaka T. RNA interference-mediated knockdown of a cytochrome P450, CYP6BG1, from the diamondback moth, Plutella xylostella, reduces larval resistance to permethrin. Insect Biochem Mol Biol. 2009;39:38-46.

45. Carmichael SN, Bron JE, Taggart JB, Ireland JH, Bekaert M, Burgess STG, et al. Salmon lice (Lepeophtheirus salmonis) showing varying emamectin benzoate susceptibilities differ in neuronal acetylcholine receptor and GABA-gated chloride channel mRNA expression. BMC Genomics. 2013;14:408.
46. Poley JD, Braden LM, Messmer AM, Whyte SK, Koop BF, Fast MD. Cypermethrin exposure induces metabolic and stress-related gene expression in copepodid salmon lice (Lepeophtheirus salmonis). Comp Biochem Physiol Part D Genomics Proteomics. 2016;20:74-84.

47. Carmona-Antoñanzas G, Humble JL, Carmichael SN, Heumann J, Christie HRL, Green DM, et al. Time-to-response toxicity analysis as a method for drug susceptibility assessment in salmon lice. Aquaculture. 2016:464:570-5.

48. Carmona-Antoñanzas G, Carmichael SN, Heumann J, Taggart JB, Gharbi $\mathrm{K}$, Bron JE, et al. A survey of the ATP-binding cassette (ABC) gene superfamily in the salmon louse (Lepeophtheirus salmonis). PLoS One. 2015;10:e0137394.

49. Han J, Won EJ, Hwang DS, Shin KH, Lee YS, Leung KM, et al. Crude oil exposure results in oxidative stress-mediated dysfunctional development and reproduction in the copepod Tigriopus japonicus and modulates expression of cytochrome P450 (CYP) genes. Aquat Toxicol. 2014;152:308-17.

50. Han J, Won EJ, Kim HS, Nelson DR, Lee SJ, Park HG, et al. Identification of the full 46 cytochrome P450 (CYP) complement and modulation of CYP expression in response to water-accommodated fractions of crude oil in the cyclopoid copepod Paracyclopina nana. Environ Sci Technol. 2015:49:6982-92.

51. Baldwin WS, Marko PB, Nelson DR. The cytochrome P450 (CYP) gene superfamily in Daphnia pulex. BMC Genomics. 2009;10:169.

52. Tijet N, Helvig C, Feyereisen R. The cytochrome P450 gene superfamily in Drosophila melanogaster: annotation, intron-exon organization and phylogeny. Gene. 2001;262:189-98.

53. Nelson DR. Cytochrome P450 Nomenclature. In: Phillips IR, Shephard EA, editors. Cytochrome P450 protocols. Totowa: Humana Press; 2004. p. $1-10$.

54. Claudianos C, Ranson H, Johnson RM, Biswas S, Schuler MA, Berenbaum MR, et al. A deficit of detoxification enzymes: pesticide sensitivity and environmental response in the honeybee. Insect Mol Biol. 2006;15:615-36.

55. Russell DJ. GramAlign: fast alignment driven by grammar-based phylogeny. Methods Mol Biol. 2014;1079:171-89.

56. Nguyen LT, Schmidt HA, Von Haeseler A, Minh BQ. IQ-TREE: a fast and effective stochastic algorithm for estimating maximum-likelihood phylogenies. Mol Biol Evol. 2015;32:268-74.

57. Pfaffl MW. Quantification strategies in real-time PCR. In: Bustin SA, editor. A-Z of quantitative PCR. La Jolla, CA, USA: International University Line; 2004. p. 87-112.

58. Rice WR. Analyzing tables of statistical tests. Evolution. 1989;43:223-5.

59. Sevatdal S, Horsberg TE. Determination of reduced sensitivity in sea lice (Lepeophtheirus salmonis Krøyer) against the pyrethroid deltamethrin using bioassays and probit modelling. Aquaculture. 2003;218:21-31.

60. Lees F, Baillie M, Gettinby G, Revie CW. The efficacy of emamectin benzoate against infestations of Lepeophtheirus salmonis on farmed Atlantic salmon (Salmo salar L.) in Scotland, 2002-2006. PLoS One. 2008:3:e1549.

61. Wondji CS, Morgan J, Coetzee M, Hunt RH, Steen K, Black WC, et al. Mapping a quantitative trait locus (QTL) conferring pyrethroid resistance in the African malaria vector Anopheles funestus. BMC Genomics. 2007;8:34.

62. Sonoda S. Molecular analysis of pyrethroid resistance conferred by target insensitivity and increased metabolic detoxification in Plutella xylostella. Pest Manag Sci. 2010;66:572-5.

63. Riga M, Tsakireli D, llias A, Morou E, Myridakis A, Stephanou EG, et al. Abamectin is metabolized by CYP392A16, a cytochrome P450 associated with high levels of acaricide resistance in Tetranychus urticae. Insect Biochem Mol Biol. 2014;46:43-53.

64. Pu X, Yang Y, Wu S, Wu Y. Characterisation of abamectin resistance in a field-evolved multiresistant population of Plutella xylostella. Pest Manag Sci. 2010;66:371-8.

65. Nelson DR, Goldstone JV, Stegeman JJ. The cytochrome P450 genesis locus: the origin and evolution of animal cytochrome P450s. Philos Trans R Soc Lond B Biol Sci. 2013;368:20120474.

66. Nelson DR. Cytochrome P450 diversity in the tree of life. Biochim Biophys Acta Proteins Proteom. 2018;1866:141-54.

67. Dejong CA, Wilson JY. The cytochrome P450 superfamily complement (CYPome) in the annelid Capitella teleta. PLoS ONE. 2014;9:e107728.

68. Berenbaum MR. Postgenomic chemical ecology: from genetic code to ecological interactions. J Chem Ecol. 2002;28:873-96. 
69. Feyereisen R. Arthropod CYPomes illustrate the tempo and mode in P450 evolution. Biochim Biophys Acta. 2011;1814:19-28.

70. Daimon T, Shinoda T. Function, diversity, and application of insect juvenile hormone epoxidases (CYP15). Biotechnol Appl Biochem. 2013;60:82-91.

71. Qu Z, Kenny NJ, Lam HM, Chan TF, Chu KH, Bendena WG, et al. How did arthropod sesquiterpenoids and ecdysteroids arise? Comparison of hormonal pathway genes in noninsect arthropod genomes. Genome Biol Evol. 2015;7:1951-9.

72. Sin YW, Kenny NJ, Qu Z, Chan KW, Chan KWS, Cheong SP, et al. Identification of putative ecdysteroid and juvenile hormone pathway genes in the shrimp Neocaridina denticulata. Gen Comp Endocrinol. 2015;214:167-76.

73. Beckstead RB, Lam G, Thummel CS. Specific transcriptional responses to juvenile hormone and ecdysone in Drosophila. Insect Biochem Mol Biol. 2007;37:570-8.

74. Chang ES, Mykles DL. Regulation of crustacean molting: a review and our perspectives. Gen Comp Endocrinol. 2011;172:323-30.

75. Guittard E, Blais C, Maria A, Parvy J-P, Pasricha S, Lumb C, et al. CYP18A1, a key enzyme of Drosophila steroid hormone inactivation, is essential for metamorphosis. Dev Biol. 2011;349:35-45.

76. Sandlund L, Kongshaug H, Horsberg TE, Male R, Nilsen F, Dalvin S. Identification and characterisation of the ecdysone biosynthetic genes neverland, disembodied and shade in the salmon louse Lepeophtheirus salmonis (Copepoda, Caligidae). PLoS ONE. 2018;13:e01941995.

77. Grbić M, Van Leeuwen T, Clark RM, Rombauts S, Rouzé P, Grbić V, et al. The genome of Tetranychus urticae reveals herbivorous pest adaptations. Nature. 2011:479:487-92.
78. Mykles DL. Ecdysteroid metabolism in crustaceans. J Steroid Biochem Mol Biol. 2011;127:196-203.

79. Yang T, Liu N. Genome analysis of cytochrome P450s and their expression profiles in insecticide resistant mosquitoes, Culex quinquefasciatus. PLoS ONE. 2011;6:e29418.

80. Sturm A, Cunningham P, Dean M. The ABC transporter gene family of Daphnia pulex. BMC Genomics. 2009;10:170.

81. Eichner C, Frost P, Dysvik B, Jonassen I, Kristiansen B, Nilsen F. Salmon louse (Lepeophtheirus salmonis) transcriptomes during post molting maturation and egg production, revealed using EST-sequencing and microarray analysis. BMC Genomics. 2008;9:126.

82. Hotard K, Zou E. Does crustacean ethoxyresorufin O-deethylase activity vary during the molting cycle? Environ Toxicol Chem. 2013;32:2345-8.

83. Dam E, Rewitz KF, Styrishave B, Andersen O. Cytochrome P450 expression is moult stage specific and regulated by ecdysteroids and xenobiotics in the crab Carcinus maenas. Biochem Biophys Res Commun. 2008;377:1135-40.

84. Poley JD, Sutherland BJ, Jones SR, Koop BF, Fast MD. Sex-biased gene expression and sequence conservation in Pacific and Atlantic salmon lice (Lepeophtheirus salmonis). BMC Genomics. 2016;17:483.

\section{Publisher's Note}

Springer Nature remains neutral with regard to jurisdictional claims in published maps and institutional affiliations.
Ready to submit your research? Choose BMC and benefit from:

- fast, convenient online submission

- thorough peer review by experienced researchers in your field

- rapid publication on acceptance

- support for research data, including large and complex data types

- gold Open Access which fosters wider collaboration and increased citations

- maximum visibility for your research: over $100 \mathrm{M}$ website views per year

At BMC, research is always in progress.

Learn more biomedcentral.com/submissions 